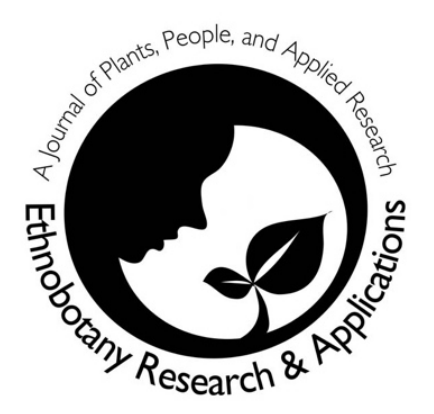

\section{Quilombola perceptions about plant-mediated ecological interactions}

\author{
Kênia Maria Oliveira Valadares, Fernanda Ribeiro da \\ Silva, Natalia Hanazaki
}

\section{Research}

\begin{abstract}
Background: Networks are useful tools to show ecological interactions because they allow to virtually represent natural structures. When applied to local knowledge this approach can reveal unnoticed perspectives, going beyond the species known and used, and showing the interdependence among them. We aim to investigate the ecological interactions between plants-and-animals and plantsand-plants perceived by people from three Quilombola groups in Southern Brazil. We also discuss how the proximity to urban areas can influence these perceptions.
\end{abstract}

Methods: Through 141 ethnobotany interviews in three communities, we asked about the plants known and how each plant interacts with other plants and with animals.

Results: The networks formed were similar in the three communities and had characteristics of freescale networks. The main interactions perceived were between cultivated plants, and between plants and native animals, and were especially related to competition, facilitation, inquilinism, and herbivory. Manihot esculenta, Citrus sinensis, Psidium guajava, and Zea mays were species with the highest centrality. Ecological interactions among different species, especially the native ones, were more prone to occur in less urbanized areas, due to proximity to forested sites.

Conclusions: The refined understanding of ecological interactions amidst traditional people reinforces the importance to preserve and maintain their knowledge beyond the simple species' records, to assist traditional people to guide their claims to establish their rights.

Keywords: Ecological interaction networks, local ecological knowledge, Quilombola communities, traditional people, ethnoecology.

\begin{tabular}{|l}
\hline Correspondence \\
Kênia Maria Oliveira Valadares ${ }^{1,2,3}$, Fernanda \\
Ribeiro da Silva ${ }^{3,4}$, Natalia Hanazaki ${ }^{1,3,4}{ }^{*}$ \\
${ }^{1}$ Post-Graduation Programme in Ecology, Federal \\
University of Santa Catarina, UFSC. Campus \\
Trindade, s/n, Florianópolis/SC Brazil 88010-970 \\
${ }^{2}$ ICMBio - Instituto Chico Mendes de Conservação \\
da Biodiversidade, Núcleo de Gestão Integrada \\
Aparados da Serra Geral. RS 427 Km 18, Cambará \\
do Sul/RS \\
${ }^{3}$ ECOHE - Laboratory of Human Ecology and \\
Ethnobotany. Departement of Ecology and Zoology, \\
Federal University of Santa Catarina, UFSC. \\
Campus Trindade, s/n, Florianópolis/SC Brazil \\
88010-970 \\
${ }^{4}$ Post-Graduation Programme in Biology of Fungus, \\
Algae and Plantae, Federal University of Santa \\
Catarina, UFSC. Campus Trindade, s/n, \\
Florianópolis/SC Brazil $88010-970$ \\
*Corresponding Author: natalia.hanazaki@ufsc.br \\
Ethnobotany Research \& Applications \\
20:3 (2020)
\end{tabular}

\section{Resumo}

Antecedentes: Redes são ferramentas úteis para mostrar interações ecológicas porque permitem representar virtualmente estruturas naturais. Quando aplicada ao conhecimento local, essa abordagem pode revelar perspectivas que usualmente passam despercebidas, indo além das espécies conhecidas e utilizadas e mostrando a interdependência entre elas. Nosso objetivo é investigar as interações ecológicas entre plantas e animais e plantas e plantas percebidas por pessoas de três grupos quilombolas no sul do Brasil. Também discutimos como a proximidade das áreas urbanas pode influenciar essas percepções. 
Métodos: Através de 141 entrevistas etnobotânicas em três comunidades, perguntamos sobre as plantas conhecidas e como cada planta interage com outras plantas e animais.

Resultados: As redes formadas foram semelhantes nas três comunidades e apresentavam características de redes de escala livre. As principais interações percebidas foram entre plantas cultivadas, e entre plantas e animais nativos, e foram especialmente relacionadas à competição, facilitação, inquilinismo e herbivoria. Manihot esculenta, Citrus sinensis, Psidium guajava e Zea mays foram espécies com maior centralidade nas redes. As interações ecológicas entre diferentes espécies, principalmente as nativas, ocorreram em áreas menos urbanizadas, devido à proximidade de áreas com cobertura florestal.

Conclusões: O entendimento refinado sobre as interações ecológicas entre povos tradicionais reforça a importância de preservar e manter seus conhecimentos, para além dos simples registros das espécies conhecidas, a fim dar suporte às reivindicações e direitos de povos e comunidades tradicionais.

Palavras-chave: redes de interação ecológica, conhecimento ecológico local, comunidades quilombolas, pessoas, etnoecologia.

\section{Background}

All living organisms interact with other species through diverse mechanisms that model the structure of ecosystems (Woottom \& Emmerson 2005), reflecting the collective activities of organisms and their effects on the environment. There is a growing consensus that the effects of biodiversity on ecosystem processes should be attributed more to the functional characteristics of the species and their interactions, compared to the number of species per se (Díaz \& Cabido 2001). Thus, the diversity of life results not only in diversification among species but also in the interactions that occur among them (Thompson 1996). Each organism is influenced by mutualistic, competitive, trophic, and other interactions that can impact the composition, structure, and function of ecosystems (Díaz \& Cabido 2001).

Traditional and local knowledge about ecological interactions is poorly documented because the interdependence among species is not systematically investigated. Thus, a key feature of ecosystems goes unnoticed. Nabham (2000) argues that many ethnobotanical inventories obtain only the surface of traditional knowledge about biodiversity, based on lists of species and their respective catalogs of use. These lists can be very descriptive, purely utilitarian, and do not add a lot of information about how the natural world functions from local perspectives, assuming maybe, that traditional communities are not interested in interspecific relationships or ecological processes, but only in useful species (Nabham 2000). In addition to knowledge about species and their uses, other levels of the biological organization can help in understanding ecological systems (Tilman et al. 1997) and cultures (Christensen et al. 1996). These levels of organization may involve inherent aspects of species, such as richness and attributes that show adaptation, as well as subtler aspects, such as genetic variation between populations, habitat heterogeneity, ecosystem diversity, and ecological interactions that are more difficult to measure and monitor (Nabham 2000).

Complex networks can be used as tools to delineate ecological interactions (Vasquez et al. 2009) because they possess the flexibility and generality to virtually represent natural structures, including dynamic changes in their topology (Costa et al. 2010). This approach was recently used to explore the relationship between knowledge and palm species across several Neotropical communities (Cámara-Leret et al. 2019). In ethnoecology, there are also attempts to consider ecological interactions and human perspectives using complex networks. Orr and Hallmark (2014) studied the perception of ecological interactions in a community of Balinese farmers, analyzing interaction networks based on their observation processes, and found that this knowledge had an adaptive character. Atran et al. (2002) compared ecological models of food networks and cultural variation of three groups that shared the same forest in Guatemala, with a focus on ecological knowledge, and found that these factors can determine the importance of the culture in the use of the forest, which is relevant for conservation.

Direct interactions between people and nature are critical and have different dimensions of immediateness, consciousness, intentionality, degree of human mediation, and direction of the outcomes (Soga \& Gaston 2020). Local ecological knowledge on species interactions embed several of these dimensions and can add to the understanding of how supporting ecosystem services are perceived. Among the different categories of ecosystem services, supporting and regulating services can be less perceived, sometimes representing the western scientists`view rather than local perspectives (Herbst et al. 2020, Oliveira \& Berkes 2014). 
Through the ecological network's approach, complex systems can be understood in a simple way, identifying the most important species and interactions to the function and organization of such such ecological systems. Thus, exploring ecological interactions from the perspective of local knowledge and perceptions helps to understand the links between environmental perceptions and ecosystem processes. Within these dynamic systems, the effects on the local knowledge are explored concerning rural-urban mobility (Nasuti et al. 2015), globalization (Saynes-Vásquez et al. 2013), and threats from urbanization and the interaction between people and natural areas (Furusawa et al. 2014).

This study is part of a research on Quilombola ethnobotany (see Ávila et al. 2015, 2017, Zank et al. 2016) that identified the most well-known plants in three communities in southern Brazil. Quilombolas are groups of Afro-descendant origin, with black ancestry and historical background that is generally related to oppression during the time of slavery in Brazil (Brasil 2003, Marques 2009). They occupy both rural and urbanized areas, and although their right to land is legally guaranteed, the Quilombola communities struggle for this and the maintenance and perpetuation of their culture and history, which has influenced various aspects of their natural and cultural environment, as illustrated in their agricultural, religious and social practices (Diegues et al. 2000).

We aim to identify the perceived ecological interactions between plants-and-animals and plantsand-plants, among Quilombolas who live in different distances from urban areas. Starting from their ethnobotanical repertoire, we hypothesize that people in territories further to urbanized areas would perceive more ecological interactions because of their proximity with the forest environments and their reliance to farming practices, although the most urbanized community reported the highest richness of plants, mostly cultivated and introduced (Ávila et al. 2015, 2017). The most well-known plants may comprise a greater number and variety of perceived ecological interactions, thus reinforcing the role of the ethnobotanical knowledge in understanding ecological functions and processes. The comprehension of these ecological functions and processes and the absorption of such comprehension into the body of local knowledge comprise several steps, which involve a conceptual structure relating cognition and representations. Perception is one of these steps, and since perceptual information guides decisions and actions, and shapes beliefs (Tacca 2011), it is deeply related to knowledge, but not as a simple synonym.

\section{Study Area}

In Brazil there are more than 3300 Quilombola communities recognized, however, only a few have their territories legally established (Fundação Cultural Palmares, 2019). Although their practices are recognized, changes induced by urbanization and industrialization have affected their livelihoods (Steward 2007). This process is similar to what is observed in other parts of Brazil, where the maintenance of traditional systems of resource management and their forms of political organization are become more fragile (Brondizio et al. 2009).

Among the 16 Quilombola communities of Santa Catarina State (Southern Brazil), Aldeia (hereafter $A L)$, Morro do Fortunato (MF) and Santa Cruz (SC) are located in the municipalities of Garopaba and Paulo Lopes, in areas originally with dense humid forest and Restinga phytophysiognomies (Figure 1). The estimated number of inhabitants in each community is 120 people at AL, 130 at SC, and 90 at MF. The distance among these communities is $20 \mathrm{~km}$ on average, through paved and unpaved roads. The process of legal recognition of their territories is undergoing, thus the territories sizes are not legally defined yet. In the last 30 years, the livelihoods in the three communities have changed, which until the 1960s were based on small-scale agriculture, livestock practices, and artisanal fishing for family consumption. Lately, regional changes, including growth in tourism, urbanization, and industrial activities have led some families to have more urban livelihoods (Ávila et al. 2015).

\section{Materials and Methods \\ Data collection}

After obtaining the prior consent of the communities and legal authorizations (see Declarations), we interviewed all residents over 18 years of age (both sexes) that agreed to participate in the study using a semi-structured protocol (available upon request). We estimate that between $77 \%$ and $80 \%$ of all adults were interviewed. The 184 interviews (65 interviews in $\mathrm{AL}, 56$ in SC, and 63 in MF) consisted of a freelisting of known and used plants (used for any purpose), followed by questions about the interactions of each plant. For each free-listed plant, we asked about the perceptions of the interviewee on the interactions between the plant and other species of animals or plants. When the interviewee did not understand the meaning of interactions, we asked about the plant's helpful or harmful relationships with other living beings, both plants or animals. Sometimes it was also necessary to give examples, but we were always aware to give examples of both positive and negative interactions (for example, if part of the plant was eaten by an animal, or if there was an animal that helped that 
plant in some way). Additional questions explored details of these interactions to allow an a posteriori classification. Based on the literature (Begon et al. 2006, Bertness \& Callaway 1994, Bronstein 2009, Odum \& Barret 2007, Ricklefs 2003), each interaction between a pair of plant and animal species was classified as herbivory, inquilinism, parasitism, pollination, dispersal, or amensalism; and each interaction between a pair of species of plants was classified as competition, parasitism, inquilinism, or facilitation. After the interviews were completed, we did a participatory workshop in each community to compile additional qualitative information about the perceived interactions, such as impressions about costs and benefits of the interactions to the plants and to humans. All residents from the communities were invited to the workshop, and 17 adults in Aldeia, 12 in Morro do Fortunato and 14 and Santa Cruz participated.

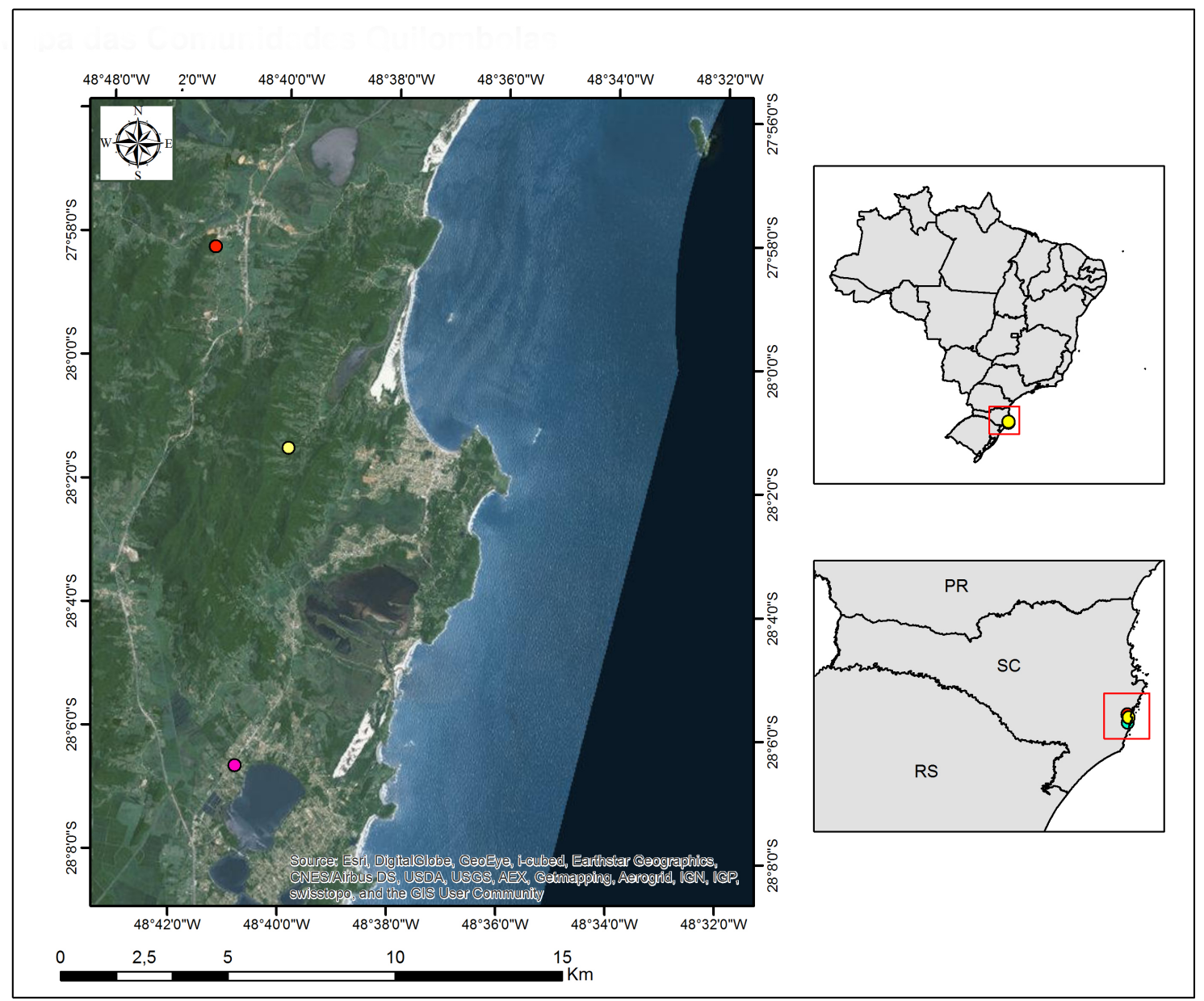

Figure 1. Study site. Pink circle: Aldeia; yellow circle: Morro do Fortunato, red circle: Santa Cruz.

The statements of the interviewees about the types of interactions were identified by codes, where the first two capital letters refer to the community ( $A L$ for Aldeia, SC for Santa Cruz and MF for Morro do Fortunato), followed by age and sex of the participant ( $\mathrm{M}$ or $\mathrm{F}$ for masculine and feminine, respectively). For example, "\#45MF76M" refers to interviewee number 45, a man from Morro do Fortunato with 76 years old.

Free-listed plants were collected or photographed (when well-known cultivated plants) for identification. Species determination followed the APG III system and was checked with literature (Lorenzi 1992, 2013,
Lorenzi \& Matos 2008) and by consulting specialists. Voucher specimens were deposited in the herbariums FLOR (Universidade Federal de Santa Catarina) and EAFM (Instituto Federal de Educação, Ciência e Tecnologia do Amazonas) under the numbers FLOR60860 to FLOR60896 and EAFM12978 to EAFM13459. The animals were identified with help of key informants, showing them illustrated guides (Antweb 2020, Marques et al. 2001, Reis et al. 2006, Souza 1998, Wikiaves 2020) and, subsequently, checking with additional literature (CBRO 2014, Caceres et al. 2007, Cherem et al. 2004, Melo \& Gonçalves 2005, Rafael 2012, Ruppert et al. 2005, Sick 2001) and consulting 
specialists. Data were collected for approximately 70 days, between 2013 and 2014 .

\section{Data analysis}

After a Shapiro-Wilk normality test, we compared the proportions of reported interactions among the communities using the Kruskal-Wallis test, and Dunn's test a posteriori. We verified the homogeneity of the reports of the plant-animal interactions in the three communities with a chi-squared test for independence. We verified the independence of the frequency of the animal interactions with plants in the reports through a G-test, as well as the frequency of different taxonomic groups of animals. Significance levels for all of the tests were $5 \%$.

We constructed interspecific, plant-animal and plantplant interaction networks for the three communities using the program NODE XL version 1.0.1.334 (Hansen et al. 2011). We used weighted matrices in which the nodes were the plant and animal species mentioned by all interviewees, expressed at the most detailed taxonomic level (class, order, or family, according to each case). The edges between the nodes represent the ecological interactions among the species. Denser edges represent a larger number of different types of interactions reported. We analyzed the structure or topology of the networks or the arrangement of links based on the organization of the information (Petchey et al. 2010). We used two centrality indexes to address which species are more important to the organization of the knowledge network: closeness centrality and betweenness centrality. Closeness centrality is based on the sum of the direct or indirect interactions (e.g. shortest distances) between one species and all other species in the network and indicates how quickly a perturbation might spread to the overall network while betweenness centrality is the number of shortest paths between two nodes that pass through a node of interest. Species with high betweenness centrality values are recognized as connectors, being important to network cohesion. Both metrics can be used to study the role and impact of species loss as well as to identify species hub (e.g. species that have much more interactions when compared with other species of the same network) (Delmas et al. 2019, González et al. 2010).

\section{Results}

The general characterization of the interviewees, as well as preliminary information about the ethnobotany of the communities, has been previously described (Ávila et al. 2015) and is summarized in Table 1. Among the 184 interviewees, 141 people (77\%) reported interactions between plants and animals (Table 2). These interactions are related to 176 plants, most of them cultivated ( $62 \%$ for $\mathrm{AL}, 66 \%$ for SC, and $55 \%$ for MF). An example of a report of plant-animal interaction is illustrated by the interview \#70MF50M for Phaseolus vulgaris: "caterpillar cuts the leaf, aracuã eats the leaf", referring to animals (Lepidoptera larvae and the bird Ortalis squamata that interact with beans by eating the leaves (two interactions of herbivory); and, for the same species: "you have to plant them wider apart so they do not disrupt each other" classified as intraspecific competition for space.

Table 1. Summary of characteristics of the studied Quilombola communities

\begin{tabular}{|llll|}
\hline & Aldeia & Santa Cruz & Morro do Fortunato \\
\hline Distance from urban area & $0 \mathrm{~km}$ & $1 \mathrm{~km}$ & $7 \mathrm{~km}$ \\
Number of households (approx.) & 40 & 24 & 32 \\
Number of interviews & 65 & 56 & 63 \\
Gender proportion (women/men) & 1.32 & 1.44 & 1.17 \\
Average age (standard deviation) & $46.8(17.7)$ & $39.6(16.1)$ & $45.7(17.3)$ \\
Percentage of people with income from urban jobs & 66 & 50 & 48 \\
Average number of plants cited per interview & 19.9 & 9.3 & 13.4 \\
Number of plant species with perceived interactions & 110 & 88 & 104 \\
\hline
\end{tabular}


Table 2. Classification of the ecological interactions according to information from the interviewees and the literature.

\begin{tabular}{lll}
\hline $\begin{array}{l}\text { Ecological } \\
\text { interactions }\end{array}$ & Characterization & Examples \\
\hline
\end{tabular}

\section{Plant-Animal interactions}

\begin{tabular}{|c|c|c|}
\hline Herbivory & $\begin{array}{l}\text { A type of predation where the animal } \\
\text { eats all or part of the plant (Ricklefs, } \\
\text { 2003). When the predator is the primary } \\
\text { consumer (normally an animal) and the } \\
\text { prey is the primary producer (plants) } \\
\text { (Odum; Barret, 2007). }\end{array}$ & $\begin{array}{l}\text { "The birds ... sabiá, saracura, tié, tucano... eat } \\
\text { the fruits" (\#69MF70F, referring to (Eriobotrya } \\
\text { japonica (Thunb.) Lindl.) eaten by different } \\
\text { birds. } \\
\text { "Saracura arrived and ate it all" (\#114MF70M), } \\
\text { referring to Aramides cajanea (Statius Muller, } \\
1776 \text { ) that eats corn (Zea mays L.). }\end{array}$ \\
\hline
\end{tabular}

Inquilinism

A particular type of commensalism where one organism lives inside or on another, definitively or temporarily, and does not cause serious damage (Dales, 1957).

\begin{tabular}{ll}
\hline Parasitism & A type of predation where the animal \\
feeds on plant tissue, generally causing \\
sickness but not necessarily death \\
(Ricklefs, 2003). Interaction between \\
two species where a population (of \\
parasites) benefits and another (host) is \\
impaired but generally does not die \\
(Odum; Barret, 2007).
\end{tabular}

Pollination A type of mutualism where the plant is assured pollination by offering resources (e.g., nectar) to flower visitors (Begon et al., 2006).

"Opossum build nest[s] in the hollow, [and] live there inside" (\#37SC43M), referring to figs (Ficus spp.) and opossum (Didelphis spp.).

"Woodpeckers and hawks build nest[s]" (\#37SC43M), referring to individuals of Celeus spp. and Falco spp., inquilines of a palm (Syagrus romanzoffiana (Cham.) Glassman.

"Plague attacks, become weak" (\#4AL29F), referring to lime tree (Citrus sp. 3).

"Larvae grow inside the fruit, you have to collect when still immature" (\#12AL40F), referring to Drosophila melanogaster (Meigen, 1830 ) that parasitizes guava fruits (Psidium guajava L.).

"Mango tree needs another mango tree on its side so the bee can exchange and the mango tree gives fruit" (\#191MF40F), referring to mango trees (Mangifera indica L.).

"Hummingbird[s] visit the flowers" (\#39AL54F), referring to species of the family Trochilidae that pollinate Malva parviflora L.

Dispersal A type of mutualism where a plant "The birds bring the seeds" (\#13AL69F), disperses its seeds by offering food referring to Eugenia uniflora L. and species of resources to animals (Begon, 2006). Passeriformes.

"Bird that planted" (\#158SC21F), referring to species of Passeriformes that disperse sunflowers (Helianthus annuus L.)

\section{Amensalism}

A population is inhibited by another and the other is not affected. A species has an evident negative effect on another but there is no detectable reciprocal effect (Odum; Barret 2007). The organism produces substances that have a toxic or repellent effect that can potentially affect other individuals (Begon, 2006).
"Animals never get close because of the smell" (\#28SC30F), referring to Ruta graveolens $\mathrm{L}$.

"Animals do not go, because it is poisonous" (\#3 AL29F), referring to Dieffenbachia amoena Bull.

"Animals do not eat, because of the smell" (\#10SC27F), referring to Melissa officinalis L.

"Strong plant, smell goes far, scares away the animals" (\#10SC27F), referring to Petiveria alliacea $\mathrm{L}$. 


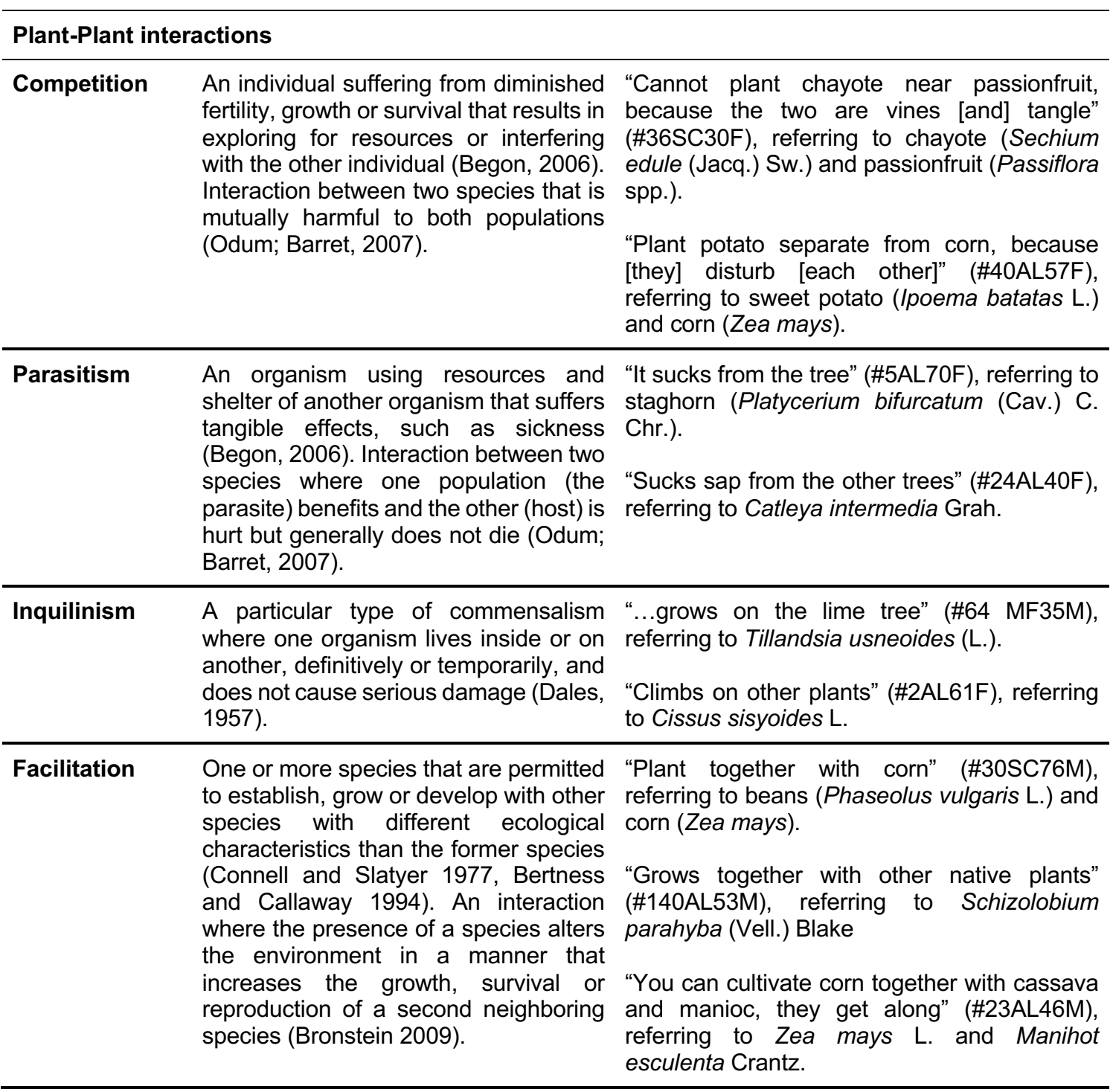

There was a significant difference between the average proportions of the reports of interactions among the communities (Kruskal Wallis $\mathrm{H}=6.993$, $p=0.0312$ ), with the highest proportion of ecological interactions for MF (the most rural community) compared to $\mathrm{AL}$ (the community closest to the urban area), but with no significant difference between SC and the other two communities. The interviewees perceived the ecological roles of plants including food source to humans and wild and domesticated animals; host plants that serve as shelter, support and nursery for diverse species of animals and other plants; mutualistic plants that exchange resources and benefits with other species through dispersal and pollination interactions; plants competing for space, light, and nutrients; and companion plants and plants that facilitate the establishment, growth, and development of other plants.

The distribution of the plant-animal interactions (Figure 2A) was significantly different for the type of interaction $(X 2=52.997, p<0.0001)$, with the perception of herbivory notably higher when compared to the other interactions $(A L=64 \%, S C$ $=58 \%, M F=66 \%$ of the total interactions reported). The frequency of reports of interacting animals by zoological class had significant differences among the communities ( $G=35.1357, p<0.0001$, Figure 3). $A L$ and $S C$ had a lower frequency of reports related to mammals; and MF had a higher frequency of reports of interactions of plants with mammals, reptiles, and mollusks. A higher frequency of insect interactions was observed for SC (Figure 3). 

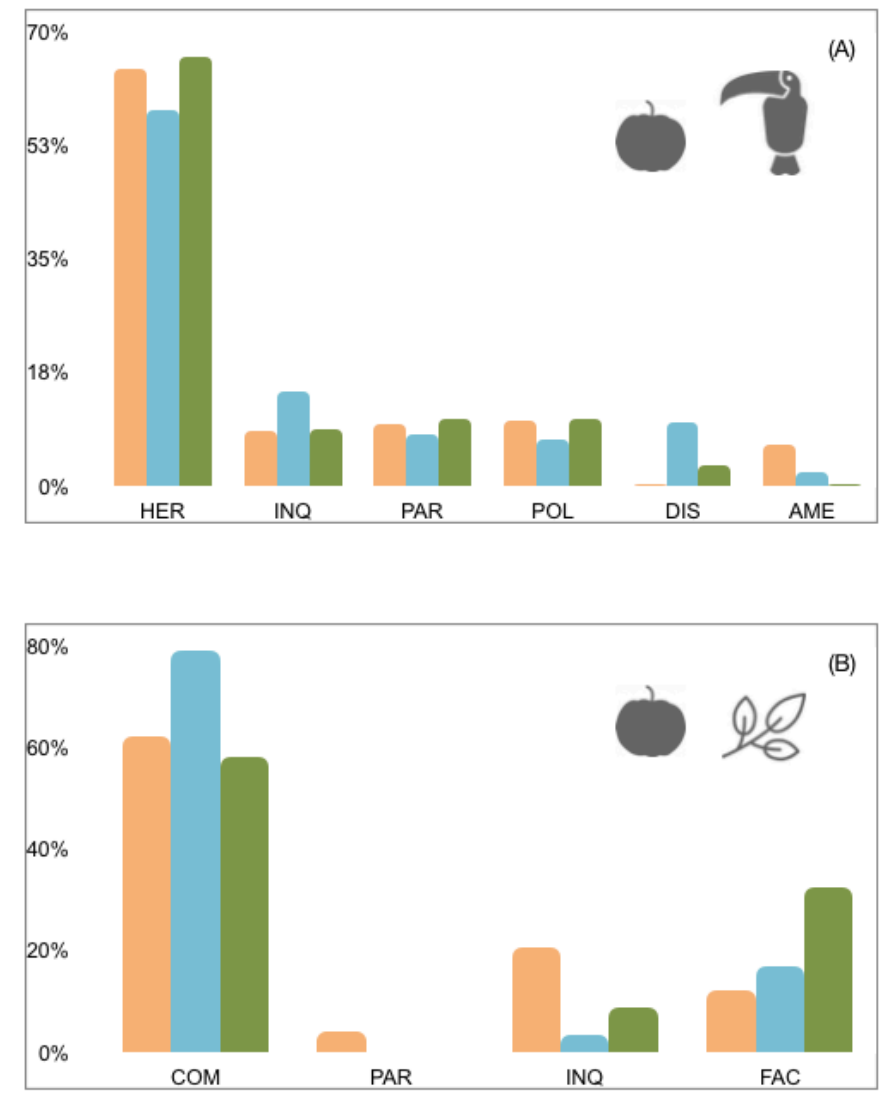

Figure 2. Frequency of citations of plants in different categories ( $A$ ) of plant-animal interactions $(A L=276, S C=275$, $M F=217$ reported plant-animal interactions); (B) of plant-plant interactions $(A L=72, S C=87, M F=175$ reported plant-plant interactions). COM- Competition, PAR- Parasitism, INQ- Inquilinism, FAC- Facilitation, HER- Hebivory, POL- Pollination, DIS- Dispersal, AME- Amensalism.

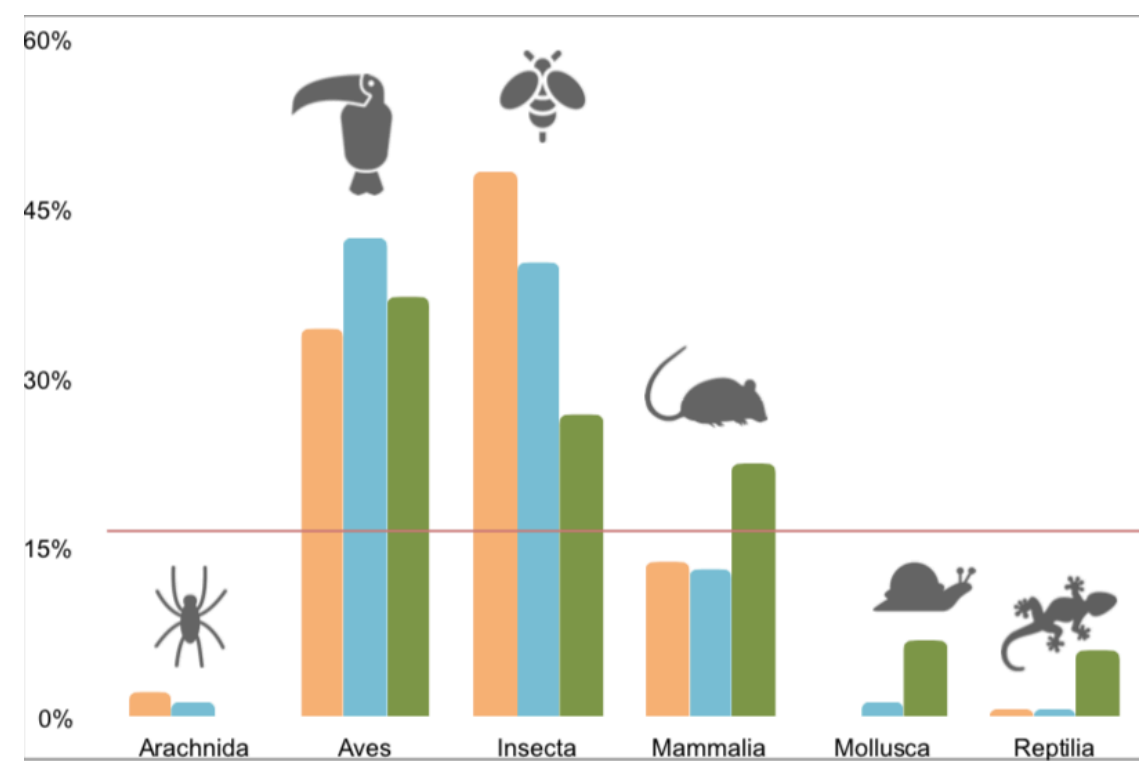

Figure 3. Frequency of reports of animals identified according to zoological class ( $A L=129$ reported animals, $\mathrm{SC}=122, \mathrm{MF}=115$ ). The red line corresponds to the average percentage. 
The distribution of the plant-plant interactions (Figure 2B) showed significant differences between the observed and expected frequencies for the different types of interactions $(G=32.8728, p<0.0001)$. The perception of competition was notably higher than the other interactions in all communities $(A L=57 \%$, SC $=75 \%$, MF $=56 \%$ of the total of interactions reported for each community). The majority of reports about plant interactions refer to local crops, such as "one plant can smother another" (\#186MF43F), referring to Arachis hypogaea. Some descriptions of interactions of competition were not related to a given species, for example, "the plants are born and grow more beautifully when they are separate from the weeds" (\#55MF52F). The perceptions of facilitation were notable for MF, with $32 \%$ of the reports for this community and $70 \%$ of the total for reports of this interaction. In MF, a combination of plants are grown in the same plot, such as Ipomoea batatas, Manihot esculenta, Phaseolus vulgaris, Saccharum officinarum, and Zea mays, which were widely mentioned as companion plants:"planting manioc and corn or beans and corn together" (\#138MF35M).

A group of plants had higher degrees (number of links) and higher values of betweenness centrality and are predominantly found in the backyards (Table 3). Higher values of betweenness centrality allow for the identification of more central species in the networks. The majority of these plants are amongst the most well-known plants in the communities and were cited by at least $25 \%$ of the interviewees (Ávila et al. 2015), such as Ipomoea batatas, Citrus sinensis, Musa paradisiaca, Psidium guajava, Lactuca sativa, Citrus spp., Andropogon citratus, Laurus nobilis, Manihot esculenta, Phaseolus vulgaris, Zea mays, Melissa officinalis, and Plectranthus barbatus. The main plants with perceived interactions are cultivated species, with also some native species (e.g., Ficus cestrifolia).

The density of the networks was similar for the three communities (Table 4), showing that the networks are alike in accessibility among the vertices. The networks exhibited characteristics of free-scale networks formed by a reduced number of highly connected vertices (hubs) and a large number of poorly connected vertices.

The network of perceived interactions between plants-plants and plants-animals in Aldeia (Table 4, Figure 4) had the highest number of vertices and of interactions (links) when compared to the other communities, but the average betweenness centrality (Kruskal Wallis $H=0.2130$, d.f. $=2$, $p>0.05$ ) did not differ among communities. The densities of the three networks showed similar low values (Table 4), reflecting the high richness of species that are not fully connected.

Most plants with the highest values of centrality are cultivated plants (Table 3), showing their relevance in local ethnobotanical repertoires. The networks also showed groups of animals with a high number of interactions, considered as hubs that are linking a great number of vertices (Figures 4-6). For instance, the order Passeriformes (34, 29, and 24 links in AL, $\mathrm{SC}$, and MF, respectively), with various species of Turdus spp., Euphonia spp., Saltator spp. and Tangara spp. Insect groups were also frequently mentioned, such as Lepidoptera (with 17, 20 and 6 links in $A L, S C$, and $M F$, respectively) and Hymenoptera, the latter represented by Apidae (with 7, 9 and 11 links in AL, SC, and MF, respectively), notably Apis mellifera and Xylocopa spp.), and Formicidae (with 19, 21 and 7 links in AL, SC, and MF, respectively), mostly by Acromyrmex spp., Solenopsis spp. and Azteca spp. (Figures 4-6).

Table 3. Plants with higher centrality (degree $>5$ ) in the networks. Illustrations highlight the plants of centrality, based on their degree and betweenness centrality.

\begin{tabular}{llll}
\hline Community/species & Illustrated topology & Degree & Betweenness centrality \\
\hline Aldeia & & & \\
\hline Citrus sinensis L. (Osbeck) & & & \\
\hline Psidium guajava L.
\end{tabular}




\begin{tabular}{|c|c|c|}
\hline $\begin{array}{l}\text { Eriobotrya japonica (Thunb.) } \\
\text { Lindl. }\end{array}$ & 6 & 349.481 \\
\hline Manihot esculenta Crantz & 7 & 314.791 \\
\hline Musa paradisiaca L. & 5 & 251.886 \\
\hline Brassica oleracea L. & 5 & 176.951 \\
\hline Lactuca sativa L. & 5 & 141.354 \\
\hline Zea mays L. & 5 & 84.179 \\
\hline \multicolumn{3}{|l|}{ Santa Cruz } \\
\hline $\begin{array}{l}\text { Plinia trunciflora (O. Berg) } \\
\text { Kausel }\end{array}$ & 6 & 522.608 \\
\hline Citrus sinensis L. (Osbeck) & 5 & 325.802 \\
\hline Rosmarinus officinalis L. & 7 & 287.814 \\
\hline Manihot esculenta Crantz & 5 & 189.402 \\
\hline Zea mays L. & 6 & 167.752 \\
\hline \multicolumn{3}{|l|}{ Morro do Fortunato } \\
\hline Phaseolus vulgaris L. & 9 & 424.401 \\
\hline Manihot esculenta Crantz & 10 & 288.661 \\
\hline Psidium guajava L. & 7 & 264.951 \\
\hline
\end{tabular}




\begin{tabular}{|c|c|c|}
\hline Zea mays L. & 10 & 260.422 \\
\hline Passiflora edulis Sims & & 256.944 \\
\hline Saccharum officinarum $\mathrm{L}$. & 8 & 216.792 \\
\hline $\begin{array}{l}\text { Ficus cestrifolia Schott ex } \\
\text { Spreng. }\end{array}$ & 5 & 203.468 \\
\hline Andropogon citratus DC. & 8 & 124.447 \\
\hline
\end{tabular}

Table 4. Summary of metrics of the networks of perceived interactions between plants-and-plants and plants-andanimals in Aldeia ( $N=50$ interviews), Santa Cruz ( $N=41$ interviews) and Morro do Fortunato ( $N=50$ interviews).

\begin{tabular}{llllll}
\hline Community & $\begin{array}{l}\mathbf{N}^{\circ} \text { of } \\
\text { vertices }\end{array}$ & $\mathbf{N}^{\circ}$ of links & $\begin{array}{l}\text { Average } \\
\text { degree }\end{array}$ & Density & $\begin{array}{l}\text { Average betweenness } \\
\text { centrality }\end{array}$ \\
\hline Aldeia & 98 & 148 & 2.918 & 0.030 & 119.398 \\
\hline Santa Cruz & 87 & 141 & 3.034 & 0.035 & 99.586 \\
\hline Morro do Fortunato & 82 & 129 & 3.651 & 0.044 & 77.744 \\
\hline
\end{tabular}

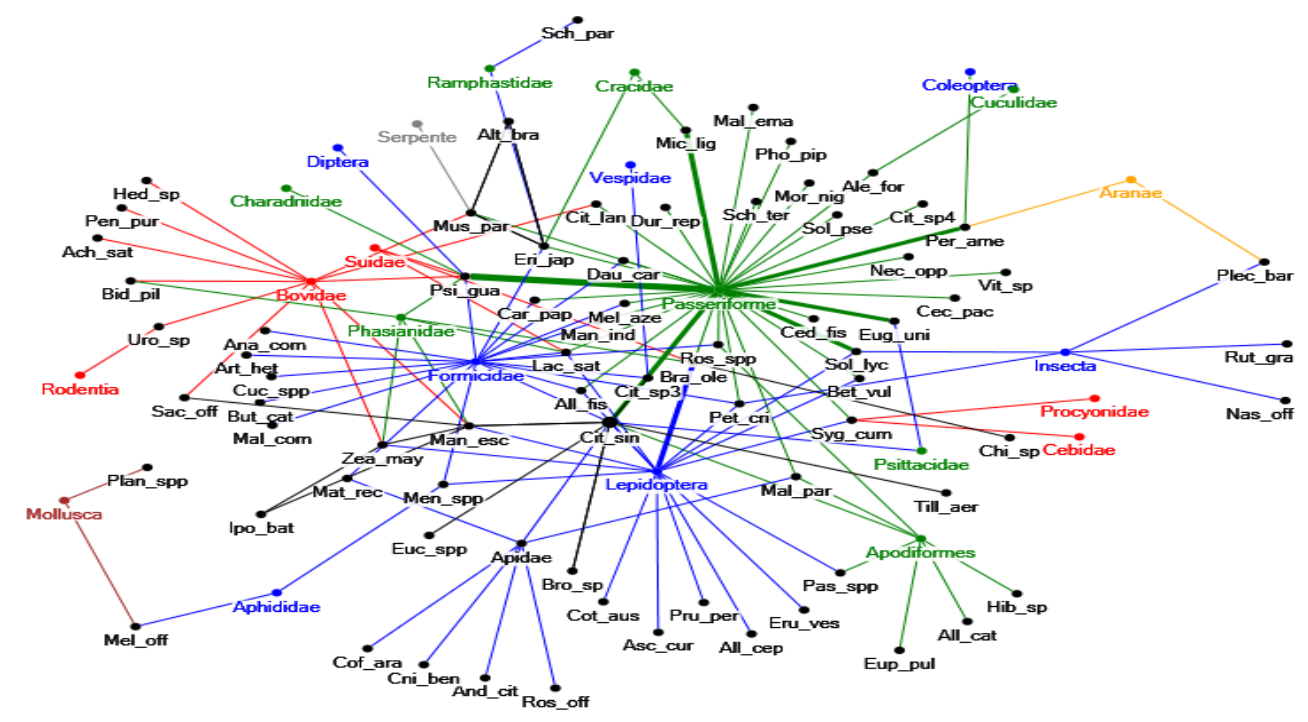

Figure 4. Network of ecological interactions between plants-and-plants and plants-and-animals, perceived by 50 interviewees of Aldeia community. Bolder links indicate a species with more interactions; blue=Insecta, grey=Reptilia, orange=Araneae, brown=Mollusca, black=Plantae, green=Aves, red=Mammalia. See full legend for species names below Figure 6 . 


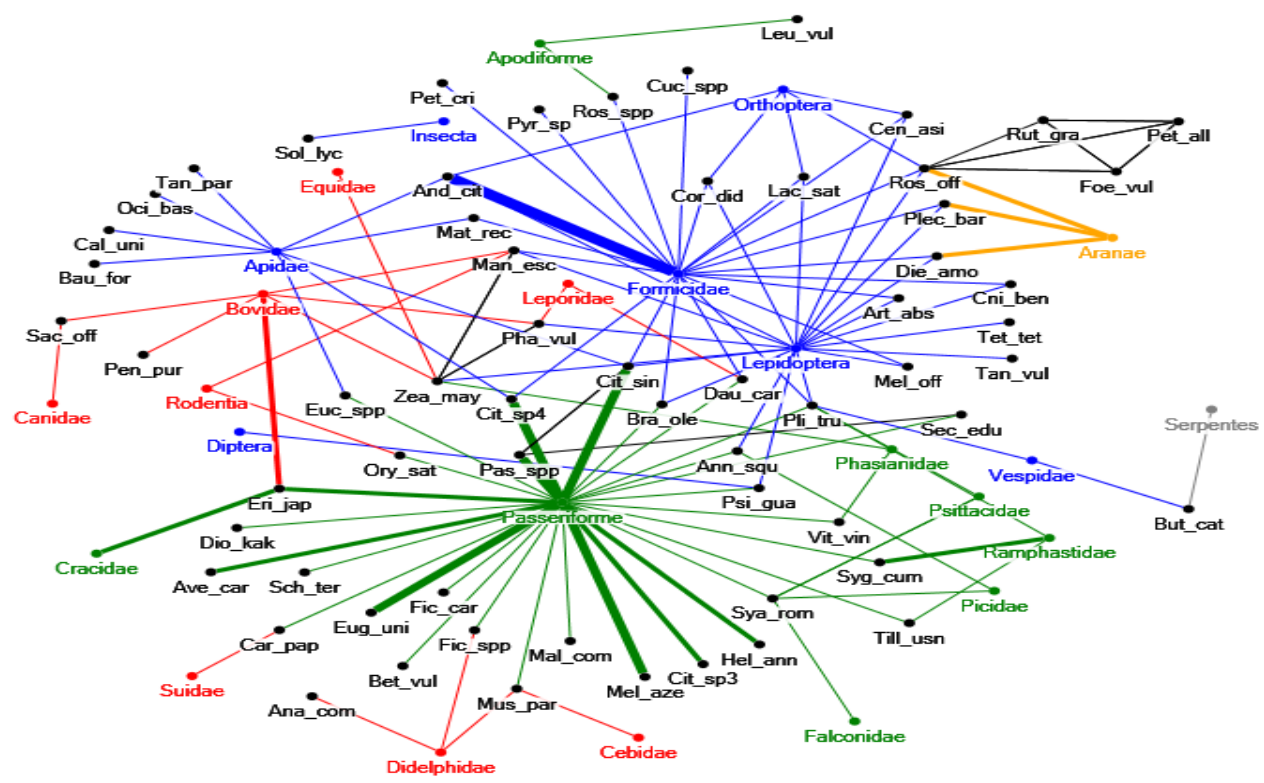

Figure 5. Network of ecological interactions between plants-and-plants and plants-and-animals, perceived by 41 interviewees of Santa Cruz community. Bolder links indicate a species with more interactions; blue=Insecta, grey=Reptilia, orange=Araneae, brown=Mollusca, black=Plantae, green=Aves, red=Mammalia. See full legend for species names below Figure 6.

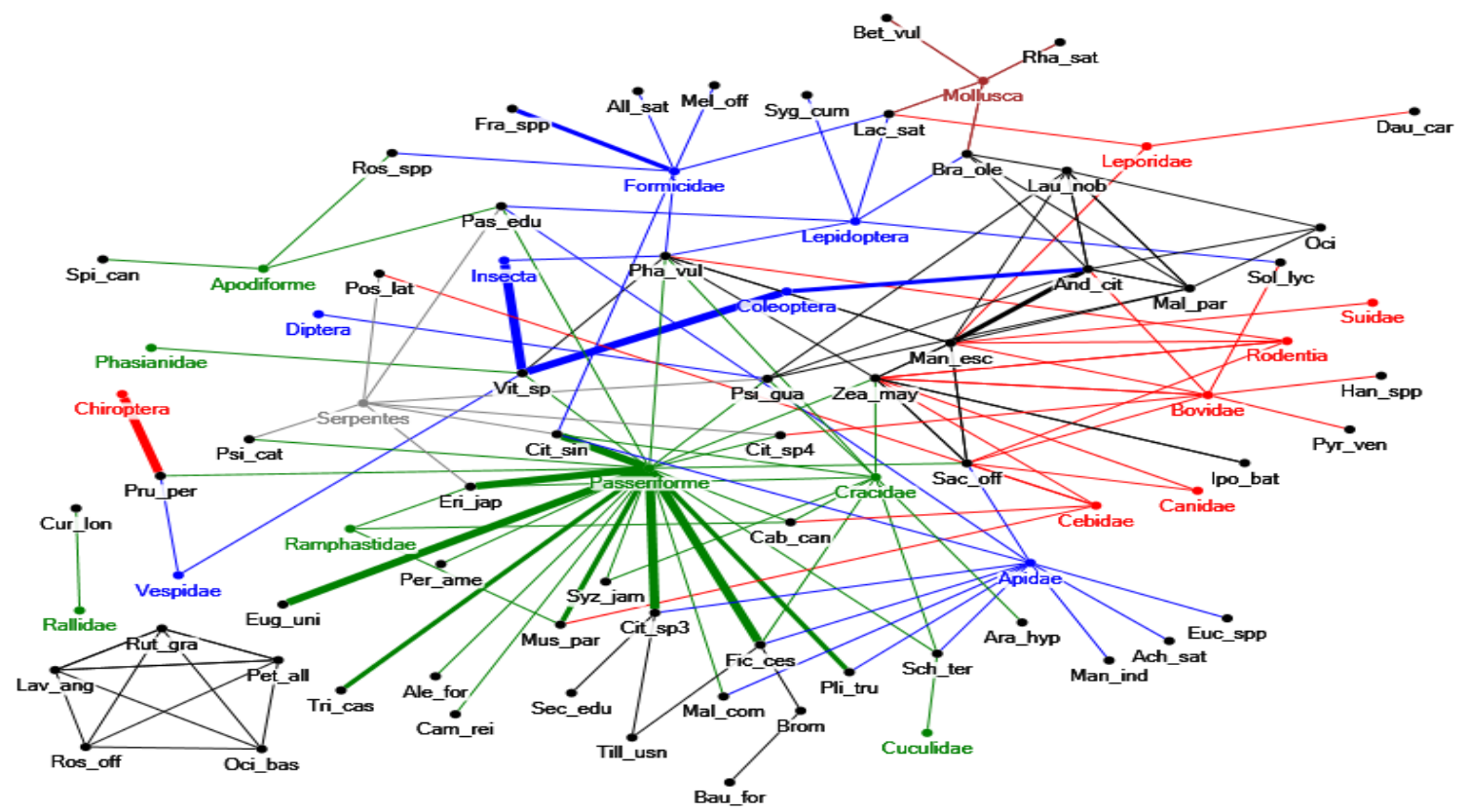

Figure 6. Network of ecological interactions between plants-and-plants and plants-and-animals, perceived by 50 interviewees of Morro do Fortunato. Bolder links indicate a species with more interactions; blue=Insecta, grey=Reptilia, orange=Araneae, brown=Mollusca, black=Plantae, green=Aves, red=Mammalia. See full legend for species names on supplementary material. 
Species Names for Figure 4-6.

Ach_sat- Achyrocline satureioides, Ale_for- Aleurites fordii, All_cat- Allamanda cathartica, All_cep- Allium cepa, All_fis- Allium fistulosum, All_sat- Allium sativum, Alt_bra- Alternanthera brasiliana, Ana_com- Ananas comosus, And_cit- Andropogon citratus, Art_het- Artocarpus heterophyllus, Asc_cur- Asclepias curassavica, Bau_forBauhinia forficata, Bet_vul- Beta vulgaris, Bid_pil- Bidens pilosa, Bra_ole- Brassica oleracea, But_cat- Butia catarinensis, Car_pap-Carica papaya, Cec_pac- Cecropia pachystachya, Ced_fis- Cedrela fissilis, Cit_lanCitrullus lanatus, Cit_sin- Citrus sinensis, Cit_sp3-Citrus sp. 3, Cit_sp4- Citrus sp. 4, Cni_ben- Cnicus benedictus, Cof_ara-Coffea arabica, Cot_aus-Cotula australis, Cuc_spp-Cucurbita spp., Dau_car-Daucus carota, Die_amoDieffenbachia amoena, Dill_ind-Dillenia indica, Dur_rep- Duranta repens, Eri_jap-Eriobotrya japonica, Eru_vesEruca vesicaria, Eug_uni- Eugenia uniflora, Eup_pul- Euphorbia pulcherrima, Fra_spp- Fragaria spp., Hed_spHedychium sp., Hib_sp- Hibiscus sp., Ipo_bat-Ipomoea batatas, Lac_sat- Lactuca sativa, Mal_ema- Malpighia emarginata, Mal_com-Malus communis, Mal_par-Malva parviflora, Man_ind-Mangifera indica, Man_esc- Manihot esculenta, Mat_rec-Matricaria recutita, Mel_aze-Melia azedarach, Mel_off-Melissa officinalis, Men_spp-Mentha spp., Mic_lig- Miconia ligustroides, Mor_nig- Morus nigra, Mus_par- Musa paradisiaca, Nas_off - Nasturtium officinale, Nec_opp- Nectandra oppositifolia, Pas_spp- Passiflora spp., Pen_pur- Pennisetum purpureum, Per_ame- Persea americana, Pet_cri- Petroselinum crispum, Pho_pip- Phoradendron piperoides, Plan_sppPlantago spp., Plec_bar- Plectranthus barbatus, Pru_per-Prunus persica, Psi_gua- Psidium guajava, Ros_sppRosa spp., Ros_off- Rosmarinus officinalis, Rut_gra- Ruta graveolens, Sac_off- Saccharum officinarum, Sam_ausSambucus australis, Sch_arb-Schefflera arboricola, Sch_ter-Schinus terebinthifolius, Sch_par-Schizolobium parahyba, Sol_lyc-Solanum lycopersicum, Sol_pse- Solanum pseudoquina, Syg_cum- Syzygium cumini, Till_aerTillandsia aeranthos, Uro_sp-Urochloa sp., Vit_sp-Vitis sp., Zea_may- Zea mays.

\section{Discussion}

The most rural community (MF, Morro do Fortunato) reported the highest proportion of ecological interactions and had a higher frequency of reports of interactions of plants with mammals, reptiles, and mollusks. Mammals require a larger habitat and have less ability to adapt to disturbed environments such as fragmented areas (Lawrance 1994). On the other hand, birds are usually more conspicuous than mammals and were frequently perceived in all communities. The outstanding proportion of interactions with insects in Aldeia can be related to the perceived herbivory in cultivated plants.

This proximity with forested areas can provide more opportunities for native species observation, which explains the presence of these animal groups in MF. However, the community closest to the urban area (AL, Aldeia, which was also the community with the highest richness of reported plants, see Ávila et al. $2015,2017)$ reported the highest number of species interacting with plants. The Quilombolas perceived the ecological interactions around the plants in different ways, which is influenced by which plants are the most important in their ethnobotanical repertoire, mostly cultivated plants. All of the communities have access to areas of forest, where plants are collected, although in AL this area is smaller and no longer belongs to the territory. The proximity to forest areas allows making more observations about nature that leads to a better, often refined understanding of ecological interactions (Atran et al. 2002, Orr \& Hallmark 2014). Additionally, the proximity with urban areas could explain differences in the perceptions of the plantplant and plant-animal interactions, due to the lack in the immediateness of these interactions, or the degree of physical interaction between a person and nature (Soga \& Gaston 2020). Indeed, the community farther from the urban area is also close to more forested areas (Ávila et al. 2015). In this community there was also a predominance of cultivated plants in larger farming plots, favoring a more accurate perception of how cultivated plants interact with other species: more dependence on farming can contribute to the consciousness and intentionality of the perceived interactions (Soga \& Gaston 2020). In MF, the different frequencies of animal interactions reveal that the nuances in the spatial configuration of the communities allow for the observation of wild and native species of fauna.

Focusing on perceived interactions between pairs of species allows us to go beyond the plants and animals known by a given human group. Perceptions of interactions are related not only to ecological patterns (e.g. the richness of plants and animals known) but also to processes (e.g. how these elements participate in ecosystem functioning) (Vellend 2010). This new perspective can add to the comprehension of the biological diversity, and ecosystem support services, as well as cultural ecosystem services (Kumar \& Nair 2004), and provision services directly accessed when asking for uses of plants for example.

Some species of plants and animals have high centrality values because they have more links that make connections to other vertices stronger and exert control over the flow between the other vertices (Freeman 1978). The networks formed are complex and exhibit characteristics of free-scale networks 
(Barabási \& Albert 1999), formed by a small number of highly connected hubs and a large number of poorly connected vertices. Networks that have such patterns of interactions are robust and can handle the random removal of links; however, they are vulnerable to attacks directed at hubs (Janssen et al. 2006, Memmott et al. 2004), such as those animals and plants with a high degree of centrality. If on one hand, it can provide more safety to the local agroecosystem structure, on the other hand, the loss of central plant species could cause disruptions in the network.

The networks have ecologically similar species in the three communities, that exhibit functional and utilitarian redundancy (Nascimento et al. 2013), which contributes to their ability to adapt to change (Folke 2006, Janssen et al. 2006). These species are predominantly cultivated in home gardens in the territories and are used every day by the Quilombolas, reflecting this characteristic of the groups of using many cultivated and introduced species (Ávila et al. 2017, Zank et al. 2016). In addition to native species, these plants contribute to increasing the diversity of the cultivated environment, which is part of the local socioecological system and help connect the users to resource units (Ostrom 2009).

The elements with high centrality are important to the cohesion of the network system (Albert \& Barabási 2002) and exhibit characteristics of complex networks (Boccaletti et al. 2006, Newman 2003, Strogatz 2001), such as irregular and dynamic structure. Complex networks prove to be an interesting tool for understanding ecological interactions based on the human perception that, when combined with other concepts, allows for more comprehensive ethnoecological analyses. Including the human element in these networks is interesting to mark links between environmental perception and the socio-ecological systems of the Quilombolas. Although the relationships are not simple, some measurements may capture essential functional implications related to the resilience of the structure of the socio-ecological network (Janssen et al. 2006). The identification of a group of plants with greater ecological centrality in the communities could contribute as a local element used in policy development (Brasil 2007, Little 2002), in a context where these communities want to not only maintain the group identity but also aim to rescue cultivation and use practices of ecologically and culturally important plants.

\section{Conclusions}

Deepening the analysis of perceived interactions between pairs of species allows going beyond the plants and animals known and used, adding to the understanding of ecological patterns and processes from a local perspective. This approach can help in better understanding ecosystem support services, especially for those services less accommodated in local perceptions such as regulation and support. Additionally, this approach can support conservation actions from the perspective of community participation (Berkes 2004), to incorporate the needs of the Quilombolas into conservation objectives (and vice versa), such as the implementation of integrated conservation and development projects that associate the plants with ecological centrality to the sociocultural context of the communities. Such projects should consider the dimension, amplitude, and complexity of the local knowledge, within the Quilombola socio-ecological systems, to guarantee harmony between local development and the conservation of biodiversity. This information could contribute with elements of local governance (Graham et al. 2003) through the incorporation of local ecological perspectives to make decisions (Newing \& Firtsch 2009), not only in everyday practices but also as a way of empowerment and recognition of the wealth of local ecological knowledge the community members have. This would strengthen the consolidation of the rights of the traditional communities, allowing agreements around the use and conservation of natural resources, something that is often neglected.

\section{Declarations}

List of abbreviations: APG III - Angiosperm Phylogeny Group; EAFM - Herbarium of Instituto Federal de Educação, Ciência e Tecnologia do Amazonas; FLOR - Herbarium of Universidade Federal de Santa Catarina

Ethics approval and consent to participate: This research was approved by Conselho de Ética e Pesquisa com Seres Humanos at the Universidade Federal de Santa Catarina (18847013.0.0000.0121), for research ethics with human beings; and was approved by IPHAN (Instituto do Patrimônio Histórico e Artístico Nacional) for access to traditional knowledge (01450.012607/2013-20). All participants (interviewees) agreed with an individual free informed consent term.

Consent for publication: Not applicable

Availability of data and materials: Please indicate if any datasets have been deposited in public repositories.

Competing interests: We have no competing interests.

Funding: This study was financed in part by the Coordenação de Aperfeiçoamento de Pessoal de Nível Superior - Brasil (CAPES) - Finance Code 001. N. Hanazaki thanks CNPq for the productivity research grant (306478/2012-9 and 309613/2015-9) 
Co-funding: Not applicable

Authors' contributions: KMOV designed the research, collected the data, analyzed and discussed the data and wrote the text; FR analyzed and discussed the data and contributed with the final text; $\mathrm{NH}$ designed the research, analyzed and discussed the data and wrote the text.

\section{Acknowledgements}

We especially thank the Aldeia, Morro do Fortunato and Santa Cruz Quilombola communities for participating in the project; the specialists on botany (A. Mello, R.Trevisan, M. Bereta, P. C. Simionato) and zoology (A.P.T. Moreira, B.C.Lopes, F.B. Farias, J. Steiner, L.G.O. Santos, M. Graipel) who helped in species identification; M.L. Mina (Movimento Negro Unificado de Santa Catarina) helped in the first contacts with the communities; S.Zank, J.V.C.Ávila, J.Maragno and other collaborators helped with data collection; A. Schiavetti, T.T. Castellani, T.M.Miranda, G.D. Blanco, R.H. Ludwinsky, S.Zank, D.Cantelli, H. Assis, and B.S.Santos provided important insights for the manuscript.

\section{Literature Cited}

Albert R, Barabási AL. 2002. Statistical mechanics of complex networks. Reviews of Modern Physics 74:47-97.

Atran S, Medin D, Ross N, Lynch E, Vapnarsky V, Ucan Ek' E, Coley J, Timura C, Baran M. 2002. Folkecology, Cultural Epidemiology, and the Spirit of Commons. Current Anthropology 43(3):1-23.

Antweb. 2020. Antweb version 8.17.3. Available at <http://antweb.org> accessed 23 March 2020.

Ávila JVC, Zank S, Valadares KMO, Maragno J, Hanazaki N. 2015. The traditional knowledge of Quilombola about plants:does urbanization matter? Ethnobotany Research and Applications 14:453462.

Ávila JV, Mello AS, Beretta ME, Trevisan R, Fiaschi P, Hanazaki N. 2017. Agrobiodiversity and in situ conservation in quilombola home gardens with different intensities of urbanization. Acta Botanica Brasilica 31:1-10.

Barabási AL, Albert R. 1999. Emergence of scaling in random networks. Science 286:509-511.

Begon M, Townsed CR, Harper JL. 2006. Ecology. From individuals to ecossystems. 4th ed. Blackwell Publishing, London, U.K.

Berkes F. 2004. Rethinking community-based conservation. Conservation Biology 18:621-630.

Bertness M, Callaway R. 1994. Positive interactions in communities. Tree 9:191-193.
Boccaletti S, Latora V, Moreno Y, Chavez M, Hwan, DU. 2006. Complex networks:Strucuture and dynamics. Physics Reports 424:175-308.

Brasil. 2003. Decreto $n^{\circ}$ 4.887. Available at <http://www.planalto.gov.br/ccivil 03/decreto/2003/ D4887.htm > accessed 23 March 2020

Brasil. 2007. Decreto $n^{\circ}$ 6.040. Available at <http://www.planalto.gov.br/ccivil_03/_ato20072010/2007/decreto/d6040.htm> accessed 23 March 2020

Brondizio ES, Ostrom E, Young OR. 2009. Connectivity and the governance of multilevel socialecological systems:the role of social capital. Annual review of environment and resources 34:253-78.

Bronstein JL. 2009. The evolution of facilitation and mutualism. Journal of Ecology 97:1160-1170.

Caceres NC, Cherem JJ, Graipel ME. 2007. Distribuição geográfica de mamíferos na região Sul do Brasil. Ciência e Ambiente 35:167-180.

Cámara-Leret R, Fortuna MA, Bascompte J. 2019. Indigenous knowledge networks in the face of global change. Proceedings of the National Academy of Sciences 116:9913-9918.

CBRO. Comitê Brasileiro de Registros Ornitológicos. 2014. Listas das Aves do Brasil. $11^{a}$ edição. CBRO, Florianópolis, Brazil.

Cherem JJ, Simões-Lopes PC, Althoff S, Graipel ME. 2004. Lista dos mamíferos do estado de Santa Catarina, sul do Brasil. Mastozoología neotropical11:151-84.

Christensen NL, Bartuska AM, Brown JH, Carpenter S, D'Antonio C, Francis R, Franklin JF, MacMahon JA, Noss RF, Parsons DJ, Peterson CH. 1996. The report of the Ecological Society of America committee on the scientific basis for ecosystem management. Ecological applications 6:665-91.

Costa LD, Rodrigues FA, Travieso G, Villas Boas PR. 2007. Characterization of complex networks:A survey of measurements. Advances in physics 56:167-242.

Delmas E, Besson M, Brice MH, Burkle LA, Dalla Riva GV, Fortin MJ, Gravel D, Guimarães Jr PR, Hembry DH, Newman EA, Olesen JM. 2019. Analysing ecological networks of species interactions. Biological Reviews 94:16-36.

Díaz S, Cabido M. 2001. Vive la différence:plant functional diversity matters to ecosystem processes. Trends in Ecology and Evolution 16:646-655.

Diegues AC, Arruda RSV, Silva VCF, Figols FAB, Andrade D. 2000. Biodiversidade e comunidades 
tradicionais no Brasil. Hucitec/NUPAUB, São Paulo, Brazil.

Folke C. 2006. Resilience:The emergence of a perspective for social-ecological systems analyses. Global Environmental Change 16:253-267.

Freeman LC. 1978. Centrality in social networks:conceptual clarification. Social Networks 1:215-239.

Fundação Cultural Palmares. 2019. Comunidades quilombolas. Available at http://www.palmares.gov.br accessed 23 November 2019.

Furusawa T, Sirikolo MQ, Sasaoka M, Ohtsuka R. 2014. Interaction between forest biodiversity and people's use of forest resources in Roviana, Solomon Islands:implications for biocultural conservation under socioeconomic changes. Journal of ethnobiology and ethnomedicine 10:10.

González AM, Dalsgaard B, Olesen JM. 2010. Centrality measures and the importance of generalist species in pollination networks. Ecological Complexity 7:36-43.

Graham J, Amos B, Plumptre TW. 2003. Governance principles for protected areas in the 21st century. Institute on Governance, Ottawa, Canada.

Hansen D, Shneiderman B, Smith MA. 2011. Analyzing social media networks with NodeXL:Insights from a connected world. Morgan Kaufmann, Burlington. USA.

Herbst DF, Gerhardinger LC, Hanazaki N. 2020. Linking User-Perception Diversity on Ecosystems Services to the Inception of Coastal Governance Regime Transformation. Frontiers in Marine Science $7: 83$.

Janssen MA, Bodin Ö, Anderies JM, Elmqvist T, Ernstson H, McAllister RR, Olsson P, Ryan P. 2006. Toward a network perspective of the study of resilience in social-ecological systems. Ecology and Society 11:15.

Kumar BM, Nair PKP. 2004. The enigma of tropical homengardens. Agroflorestry Systems. 61:135-152.

Lawrance W. 1994. Rainforest fragmentation and the structure of small mammal communities in tropical Queensland. Biological Conservation 69:23-32.

Little P. 2002. Territórios sociais e povos tradicionais no Brasil:por uma Antropologia da territorialidade. Série Antropologia 32:1-32.

Lorenzi H. 1992. Árvores brasileiras:manual de identificação e cultivo de plantas arbóreas nativas do Brasil. Vol I, II e III. Plantarum, Nova Odessa, Brazil.
Lorenzi H, Matos FJA. 2008. Plantas medicinais no Brasil:nativas e exóticas. $2^{\mathrm{a}}$ Ed. Ed. Plantarum, Nova Odessa, Brazil.

Lorenzi H. 2013. Plantas para jardim no Brasil:herbáceas, arbustivas e trepadeiras. Ed. Plantarum, Nova Odessa, Brazil.

Marques OAV, Eterovic A, Sazima I. 2001. Serpentes da Mata Atlântica:Guia ilustrado para a Serra do Mar. Holos Editora, Ribeirão Preto, Brazil.

Marques CE. 2009. De quilombos a quilombolas:notas sobre um processo históricoetnográfico. Revista de Antropologia 52:339-374.

Melo GAR, Gonçalves RB. 2005. Higher-level bee classifications (Hymenoptera, Apoidea, Apidae sensu lato). Revista Brasileira de Zoologia 22:153159.

Memmott J, Waser NM, Price MV. 2004. Tolerance of pollination networks to species extinctions. Proceedings of the Royal Society of London. Series B:Biological Sciences, 271:2605-2611.

Nabham GP. 2000. Interspecific relationships affecting endangered species recognized by O'Odham and Comcáac cultures. Ecological Applications 10:1288-1295.

Nascimento ALB, Ferreira Júnior WS, Ramos MA, Medeiros PM, Soldati GT, Santoro FR, Albuquerque UP. 2013. Redundância utilitária e funcionalidade de sistemas de conhecimento tradicional. In Etnobiologia:Bases ecológicas e evolutivas. Edited by Albuquerque UPA. NUPPEA, Recife, Brazil, Pp. 85-99.

Nasuti S, Eloy L, Raimbert C, Le Tourneau FM. 2015. Can Rural-Urban Household Mobility Indicate Differences in Resource Management within A mazonian Communities?. Bulletin of Latin American Research 34:35-52.

Newing JE, Fritsch O. 2009 Governança ambiental:participativo, multi-nível e eficaz. Política, Meio Ambiente e Governança 19:197-214.

Newman MEJ. 2003. The structure and function of complex networks. SIAM Reviews 45:167-256.

Odum E, Barrett GW. 2007. Fundamentos de Ecologia. Cengage Learning, São Paulo, Brazil.

de Oliveira LE, Berkes F. 2014. What value São Pedro's procession? Ecosystem services from local people's perceptions. Ecological economics 107:114-21.

Orr Y, Hallmark B. 2014. Folk Food Webs and the role of praxis in Substantive Ecological Knowledge. Human Ecology 42:339-346. 
Ostrom E. 2009. A general framework for analizying sustentability of social-ecological systems. Science 325:419-422.

Petchey OL, Morin PJ, Olff H. 2010. The topology of ecological interaction networks:the state of the art. In Community ecology:processes, models, and applications. Edited by Verhoef WA \& Morin PJ. Oxford University Press, New York, USA, Pp. 7-72.

Rafael JA. 2012. Insetos do Brasil. Diversidade e Taxonomia. Holos Editora, Ribeirão Preto, Brazil.

Reis NR, Peracchi AL, Pedro WA, Lima IP. 2006. Mamíferos do Brasil. Editora UEL, Londrina Brazil.

Ricklefs RE. 2003. A Economia da Natureza. $5^{\mathrm{a}}$ ed. Editora Guanabara Koogan, Rio de Janeiro, Brazil.

Ruppert EE, Fox RS, Barnes RD. 2005. Zoologia dos Invertebrados. $7^{a}$ ed., Editora Roca, São Paulo, Brazil.

Saynes-Vásquez A, Caballero J, Meave JA, Chiang F. 2013. Cultural change and loss of ethnoecological knowledge among the Isthmus Zapotecs of Mexico. Journal of ethnobiology and ethnomedicine 9:40.

Sick H. 2001. Ornitologia Brasileira. 2 vols. $3^{a}$ ed. Editora Nova Fronteira, Rio de Janeiro, Brazil.

Soga M, Gaston KJ. 2020. The ecology of humannature interactions. Proceedings of the Royal Society B 287:20191882.

Souza D. 1998. Todas as aves do Brasil. Editora Dall, Feira de Santana, Brazil.

Steward A. 2007. Nobody farms here anymore:livelihood diversification in the Amazonian community of Carvao, a historical perspective. Agriculture and Human Values 24:75-92.

Strogatz SH. 2001. Exploring complex networks. Nature 410:268-276.

Tacca MC. 2011. Commonalities between perception and cognition. Frontiers in psychology, 2:358.

Thompson JN. 1996. Evolutionary ecology and the conservation of biodiversity. Tree 11:1-4.

Tilman D, Knops J, Wedin D, Reich P, Ritchie M, Siemann E. 1997. The influence of functional diversity and composition on ecosystem processes. Science 277:1300-1302.

Vázquez DP, Blüthgen N, Cagnolo L, Chacoff NP. 2009. Uniting pattern and process in plant-animal mutualistic networks:a review. Annals of botany 103:1445-1457.

Vellend M. 2010. Conceptual synthesis in community ecology. The Quarterly review of biology 85:183-206.
Wikiaves. 2020. Available at <http://www.wikiaves.com> accessed 23 March 2020.

Wootton JT, Emmerson M. 2005. Measurement of interactions strength in nature. Annual review of ecology, evolution, and systematics 36:419-444.

Zank S, Ávila JV, Hanazaki N. 2016. Understanding the relationship between environmental health and human health in Quilombola communities of Santa Catarina. Brazilian Journal of Medicinal Plants 18:157-167. 